\title{
Evaluation of phytochemicals in select medicinal plants of the Caesalpinia species
}

\author{
K. Sivasankari, S. Janaky and T. Sekar \\ PG and Research Department of Botany, Pachaiyappa's College, Chennai-600030, India \\ sivsankari.v@gmail.com
}

\begin{abstract}
A comparative study of phytochemicals was made on leaf extracts of two herbal plants- Caesalpinia pulcherrima Swartz (a domesticated striking ornamental shrub) and Caesalpinia bonduc (L) Roxb (a wild spiny shrub) belonging to the family Caesalpinaceae. The leaf extracts were prepared with 4 different selected solvents for each plant to adjudge the major active principle in the solvent that has value in rational drug design. The qualitative analysis of phytochemicals encompasses carbohydrates, tannins, saponins, flavonoids, alkaloids, betacyanins, quinones, terepenoids, phenols, glycosides, cardiac glycosides and the results were the mean values of the triplet readings. The quantitative total phenol estimation has carved out the fact that the wild plants is contributing high values for the secondary metabolites than the domesticated plant triggering the notion domestication, the need of the hour for the distinct endangered wild medicinal plants shall be done without the loss of the quality of the drug, the property of the medicinal plants as a boon to the future generation.
\end{abstract}

Keywords: Caesalpinia pulcherrima, caesalpinia bonduc, phytochemical analysis, leaf extracts.

\section{Introduction}

The medicinal plants are those that provide people with medicines to treat illness, maintain and promote health. The phytochemicals are the wide variety of compounds produced by plants manipulated wisely in the pharmacognostic drug development and treatment of the major ailments. C. pulcherrima Swartz is a leguminous, perennial, large shrub or small tree found throughout India. It is commonly known as red bird of paradise. It has several medicinal properties and is used in the treatment of ulcer, asthma, fever, tumor and skin diseases (Kirtikar \& Basu, 1935). The plant is believed to have originated from Asia, but it is widely distributed in the tropics. It grows to between $10 \mathrm{ft}-12 \mathrm{ft}$. in height and $6 \mathrm{ft}-12 \mathrm{ft}$. in width (Bailey, 1949). A recent study of this folk remedy has shown that it possesses antibacterial and antifungal properties (Ali et al., 1999). The plant is rich in many pharmaceutical active ingredients like flavonoids, carotinoids, glycosides, phenols and steroids (Guno et al., 2009). C. bonduc is a spiny, scrambling shrub that grows to $1.5 \mathrm{~m}$ in height and $6 \mathrm{~m}$ or more in extension, and has stems up to $5 \mathrm{~cm}$ in diameter or more. The stems, twigs and leaf rachises are covered with straight or curved prickles. By the presence of gray rounded seeds with a spiny cover the plant is commonly called as Gray Nicker Bean.

\section{Materials and methods}

\section{Collection \& processing of plant samples}

The leaves of $C$. pulcherrima were collected in and around the village of Semmancheri, Kanchipuram district, Tamil Nadu. The leaves of $C$. bonduc were collected in and around Thandarai Village, Kanchipuram district, Tamil Nadu. The collected samples were air dried and powdered into a uniform powder. The extracts of the samples were prepared by soaking $100 \mathrm{~g}$ of dried powder in $200 \mathrm{ml}$ of different selected solvents for $12 \mathrm{~h}$. The extracts were filtered using Whatman filter paper no. 42.
The four different solvent-extracts such as methanol, choloroform, water and petroleum ether were taken for the phytochemical analysis of the C. pulcherrima and ethanol, methanol, hexane and water-extracts were taken for phytochemical analysis of $C$. bonduc.

\section{Phytochemical screening}

The phytochemical tests were carried out for the above mentioned extracts using the standard procedures to identify the components. The phytochemical screening of the components such as carbohydrates (Benedict's,Fehling's Molisch's tests ), saponins (Kokate, 1999), flavanoids, alkaloids (Evans,1997), anthocyanin and betacyanin, quinones (Peach \& tracoy, 1955), glycosides (Evans, 1997), cardiac glycosides, terpenoids, triterpenoids (Libermann-Buchard Reagent test), phenols and tannins (Mace,1963), coumarins, acids, proteins and aminoacid (Biuret and Ninhydrin Reagent method).

The quantitative analysis of the total phenol content was also done by Folin Ciocalteu colorimetric method with gallic acid as standard $(10 \mathrm{mg} / 10 \mathrm{ml})$. All the tests were done in triplets for each concentration and the mean values were taken as the result.

Results

The results of the phytochemical screening for the 4 solvents methanol, chloroform, water, petroleum etherextracts of $C$. pulcherrima are given in the Table 1, $2 \& 3$. The presence of the carbohydrates, terepenoids, betacyanins and quinones has been seen in all the 4 solvents of $C$. pulcherrima. The presence of aminoacids and proteins were confirmed in the chloroform extracts and absent in all other extracts. The test for the phenols showed their strong presence in the chloroform extracts while their absence was much confirmed with the methanolic extracts. The anthraquinone was present only in the extract of petroleum ether. The test for the triterepenoids have not given any results with methanol, chloroform and water but a colour change was noted with 
Table 1. Results of qualitative analysis of carbohydrates, proteins $\&$ amino acids of $C$. pulcherrima.

\begin{tabular}{|c|c|c|c|c|}
\hline \multirow[b]{2}{*}{$\begin{array}{l}\text { Phytochemical } \\
\text { test }\end{array}$} & \multicolumn{4}{|c|}{ Extracts } \\
\hline & Methanol & Chloroform & Aqueous & $\begin{array}{c}\text { Petroleum } \\
\text { ether }\end{array}$ \\
\hline \multicolumn{5}{|c|}{ Test for the presence of carbohydrate } \\
\hline Benedict's test & ++ & ++ & ++ & ++ \\
\hline Fehling's test & ++ & ++ & ++ & ++ \\
\hline Molisch test & ++ & ++ & ++ & ++ \\
\hline \multicolumn{5}{|c|}{ Test for the presence of glycosides } \\
\hline $\begin{array}{c}\text { Glycosides } \\
\text { test }\end{array}$ & 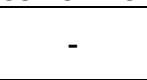 & ++ & +++ & ++ \\
\hline $\begin{array}{c}\text { Cardiac } \\
\text { glycosides }\end{array}$ & ++ & - & ++ & ++ \\
\hline \multicolumn{5}{|c|}{ Test for the presence of the protein \& amino acid } \\
\hline Ninhydrin test & - & ++ & - & - \\
\hline Biuret test & - & ++ & - & - \\
\hline
\end{tabular}

Strongly present -+++, Present - ++, Weakly present - +, Absent- -

Table 2. Results of qualitative analysis of alkaloids, flavonoids, phenols \& quinones of $C$. pulcherrima.

\begin{tabular}{|c|c|c|c|c|}
\hline \multirow{2}{*}{$\begin{array}{l}\text { Phytochemical } \\
\text { test }\end{array}$} & \multicolumn{4}{|c|}{ Extracts } \\
\hline & Methanol & Chloroform & Aqueous & $\begin{array}{c}\text { Petroleum } \\
\text { ether }\end{array}$ \\
\hline \multicolumn{5}{|c|}{ Test for presence of alkaloids } \\
\hline Wagner's test & ++ & - & - & ++ \\
\hline Hager's test & ++ & - & - & ++ \\
\hline Mayer's test & ++ & - & - & ++ \\
\hline \multicolumn{5}{|c|}{ Test for presence of flavonoid } \\
\hline Alkaline test & - & + & +++ & ++ \\
\hline \multicolumn{5}{|c|}{ Test for presence of phenols } \\
\hline $\begin{array}{c}\text { Ferric } \\
\text { Chloride test }\end{array}$ & - & +++ & ++ & ++ \\
\hline \multicolumn{5}{|c|}{ Test for presence of quinones } \\
\hline Quinones & ++ & ++ & ++ & ++ \\
\hline Anthraquinone & - & - & - & ++ \\
\hline
\end{tabular}

Table 3. Results of qualitative analysis of tannins, saponins, cyanins, phytosterols \& coumarins of $C$. pulcherrima.

\begin{tabular}{|c|c|c|c|c|}
\hline $\begin{array}{c}\text { Phytochemical } \\
\text { test }\end{array}$ & Methanol & Chloroform & Aqueous & $\begin{array}{c}\text { Petroleum } \\
\text { ether }\end{array}$ \\
\cline { 2 - 4 } & \multicolumn{4}{|c|}{ Extracts } \\
\hline \multicolumn{4}{|c|}{ Test for the presence of the tannins } \\
\hline
\end{tabular}

\section{\begin{tabular}{c|l|l|l|l}
$\begin{array}{c}\text { Ferric } \\
\text { Chloride test }\end{array}$ & +++ & ++ & ++ & - \\
\hline
\end{tabular}}

Test for the presence of the saponin

\begin{tabular}{l|l|l|l|l} 
Foam test & - & ++ & - & - \\
\hline
\end{tabular}

Test for the presence of the anthocyanin \& betacyanin

Alkaline test

\begin{tabular}{c|c|c|c|c|} 
(Anthocyanin) & - & - & - & - \\
\hline $\begin{array}{c}\text { Alkaline test } \\
\text { (Betacyanin) }\end{array}$ & ++ & ++ & ++ & ++ \\
\hline
\end{tabular}

Test for the presence of phytosterols

\begin{tabular}{|c|c|c|c|c|}
\hline $\begin{array}{c}\text { Terpenoids } \\
\text { test }\end{array}$ & ++ & ++ & ++ & ++ \\
\hline Triterpenoids & - & - & - & ++ \\
\hline \multicolumn{5}{|c|}{ Test for the presence of coumarins } \\
\hline Alkaline test & - & - & ++ & - \\
\hline
\end{tabular}

Strongly present -+++, Present - ++, Weakly present - +, Absent- -
Vol. 3 No. 12 (Dec 2010)

ISSN: 0974- 6846 the extract of petroleum ether. The results of the screening of the solvent-extracts (ethanol, methanol, hexane \& water) for phytochemicals in $C$. bonduc were given in the Table 4, $5 \& 6$. Carbohydrates, quinones, betacyanin and terepenoids were present in all 4 extracts of $C$. bonduc. The flavonoids, alkaloids, glycosides, cardiac glycosides, phenols, coumarins were present in all other extracts except that of the hexane extract. Saponins, anthraquinone, proteins and amino acids were completely absent in all the 4 selected extracts. The presence of phenol was observed in the aqueous extract of the $C$. pulcherrima and the ethanolic extract of the $C$. bonduc with each concentration in triplets. The result of the total phenol content of both the plants with the gallic acid standard was given in Graph 1.

\section{Discussion}

The medicinal value of these plants lies in some chemical substances that have a definite physiological action on the human body. The most important of these bioactive constituents of plants are alkaloids, tannins, flavanoids and phenolic compounds (Hill, 1952). Previous studies on $C$. pulcherrima led to the isolation of several diterepenoids and flavonoids (Che et al., 1986; Srinivas et al., 2003). The anti-inflammatory effects of flavonoids isolated from $C$. pulcherrima have been reported (Rao et al., 2005). It was correletated with the obtained result that C. pulcherrima has shown the presence of the flavanoids and the terepenoids in all the extracts of methanol, chloroform, water and petroleum ether. Pure flavonoids and aqueous extracts of $C$. pulcherrima Swartz were used in experiments to test their influence on a variety of viruses (Chiang et al., 2003). The present study also proved the presence of alkaloid in methanolic and petroleum ether extracts. The presence of phenol was also significant in all the extracts other than the methanolic extracts.

Table 4. Results of qualitative analysis of carbohydrates, proteins \& amino acids of $C$. bonduc.

\begin{tabular}{|c|c|c|c|c|}
\hline \multirow{2}{*}{$\begin{array}{l}\text { Phytochemical } \\
\text { test }\end{array}$} & \multicolumn{4}{|c|}{ Extracts } \\
\hline & Ethanol & Methanol & Hexane & Aqueous \\
\hline \multicolumn{5}{|c|}{ Test for the presence of carbohydrate } \\
\hline Benedict's test & ++ & ++ & ++ & ++ \\
\hline Fehling's test & ++ & ++ & ++ & ++ \\
\hline Molisch test & ++ & ++ & ++ & ++ \\
\hline \multicolumn{5}{|c|}{ Test for the presence of glycosides } \\
\hline $\begin{array}{c}\text { Glycosides } \\
\text { test }\end{array}$ & ++ & ++ & - & ++ \\
\hline $\begin{array}{c}\text { Cardiac } \\
\text { glycosides }\end{array}$ & ++ & ++ & - & ++ \\
\hline \multicolumn{5}{|c|}{ Test for the presence of protein \& amino acid } \\
\hline Ninhydrin test & - & - & - & - \\
\hline Biuret test & - & - & - & - \\
\hline
\end{tabular}

Phytochemical screening of methanolic extracts revealed the presence of alkaloids, saponins, flavonoids,
Research article

CIndian Society for Education and Environment (iSee)
"Phytochemicals in Caesalpinia spp." http://www.indjst.org
Sivasankari et al. Indian J.Sci.Technol. 
Table 5. Results of qualitative analysis of alkaloids, flavonoids, phenols and quinones of C. bonduc.

\begin{tabular}{|c|c|c|c|c|}
\hline $\begin{array}{c}\text { Phytochemical } \\
\text { test }\end{array}$ & \multicolumn{5}{c|}{ Extracts } \\
\cline { 2 - 5 } & Ethanol & Methanol & Hexane & Aqueous \\
\hline \multicolumn{5}{|c|}{ Test for presence of alkaloids } \\
\hline Wagner's test & ++ & ++ & - & ++ \\
\hline Hager's test & ++ & ++ & - & ++ \\
\hline Mayer's test & ++ & ++ & - & ++ \\
\hline \multicolumn{5}{|c|}{ Test for presence of flavonoid } \\
\hline Alkaline test & ++ & ++ & - & ++ \\
\hline \multicolumn{6}{|c|}{ Test for presence of phenols } \\
\hline $\begin{array}{c}\text { Ferric chloride } \\
\text { test }\end{array}$ & ++ & ++ & - & ++ \\
\hline \multicolumn{6}{|c|}{ Test for presence of quinones } \\
\hline Quinones & ++ & ++ & ++ & ++ \\
\hline Anthraquinone & - & - & - & - \\
\hline Strongly present -+++, Present - ++, Weakly present - +,
\end{tabular}

tannins and steroids (Gupta et al., 2004). It was controversial that Saponins were absent in the methanolic extract of the present study while all other above mentioned metabolites are significantly present in all the extracts in unison with previous studies. The extract of hexane has given fewer active ingredients when compared with the other solvent-extracts. The methanol extract of $C$. bonducella leaves containing flavonoids and triterpenoids, the antioxidant defense system has been evaluated (Gupta et al., 2005). All other phytochemical components discussed here are present in the present study of the $\mathrm{C}$. bonduc. The phenolic
Table 6. Results of qualitative analysis of tannins, saponins, cyanins, phytosterols \& coumarins of $C$. bonduc.

\begin{tabular}{|c|c|c|c|c|}
\hline \multirow{2}{*}{$\begin{array}{c}\text { Phytochemical } \\
\text { test }\end{array}$} & \multicolumn{4}{|c|}{ Extracts } \\
\hline & Ethanol & Methanol & Hexane & Aqueous \\
\hline \multicolumn{5}{|c|}{ Test for the presence of the Tannins } \\
\hline $\begin{array}{c}\text { Ferric chloride } \\
\text { test }\end{array}$ & +++ & ++ & 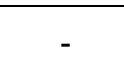 & ++ \\
\hline \multicolumn{5}{|c|}{ Test for the presence of the saponin } \\
\hline Foam test & - & - & - & - \\
\hline \multicolumn{5}{|c|}{ Test for the presence of the anthocyanin \& betacyanin } \\
\hline $\begin{array}{c}\text { Alkaline test } \\
\text { (Anthocyanin) }\end{array}$ & 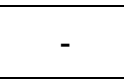 & - & 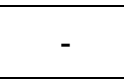 & ( \\
\hline $\begin{array}{l}\text { Alkaline test } \\
\text { (Betacyanin) }\end{array}$ & ++ & ++ & ++ & ++ \\
\hline \multicolumn{5}{|c|}{ Test for the presence of phytosterols } \\
\hline $\begin{array}{c}\text { Terpenoids } \\
\text { test }\end{array}$ & ++ & ++ & + & ++ \\
\hline Triterpenoids & ++ & ++ & - & - \\
\hline \multicolumn{5}{|c|}{ Test for the presence of coumarins } \\
\hline Alkaline test & ++ & ++ & - & ++ \\
\hline
\end{tabular}

compound has several functions such as singlet and triplet oxygen quenchers, free radical scavengers, peroxide decomposers, enzyme inhibitors and synergists (Zhang et al., 2004). The qualitative analysis have shown the presence of phenol in all the extracts performed other than the hexane for $C$. bonduc and methanol for $C$. pulcherrima. The agro climatic conditions shall be made conducive for domesticating new exotic plant varieties

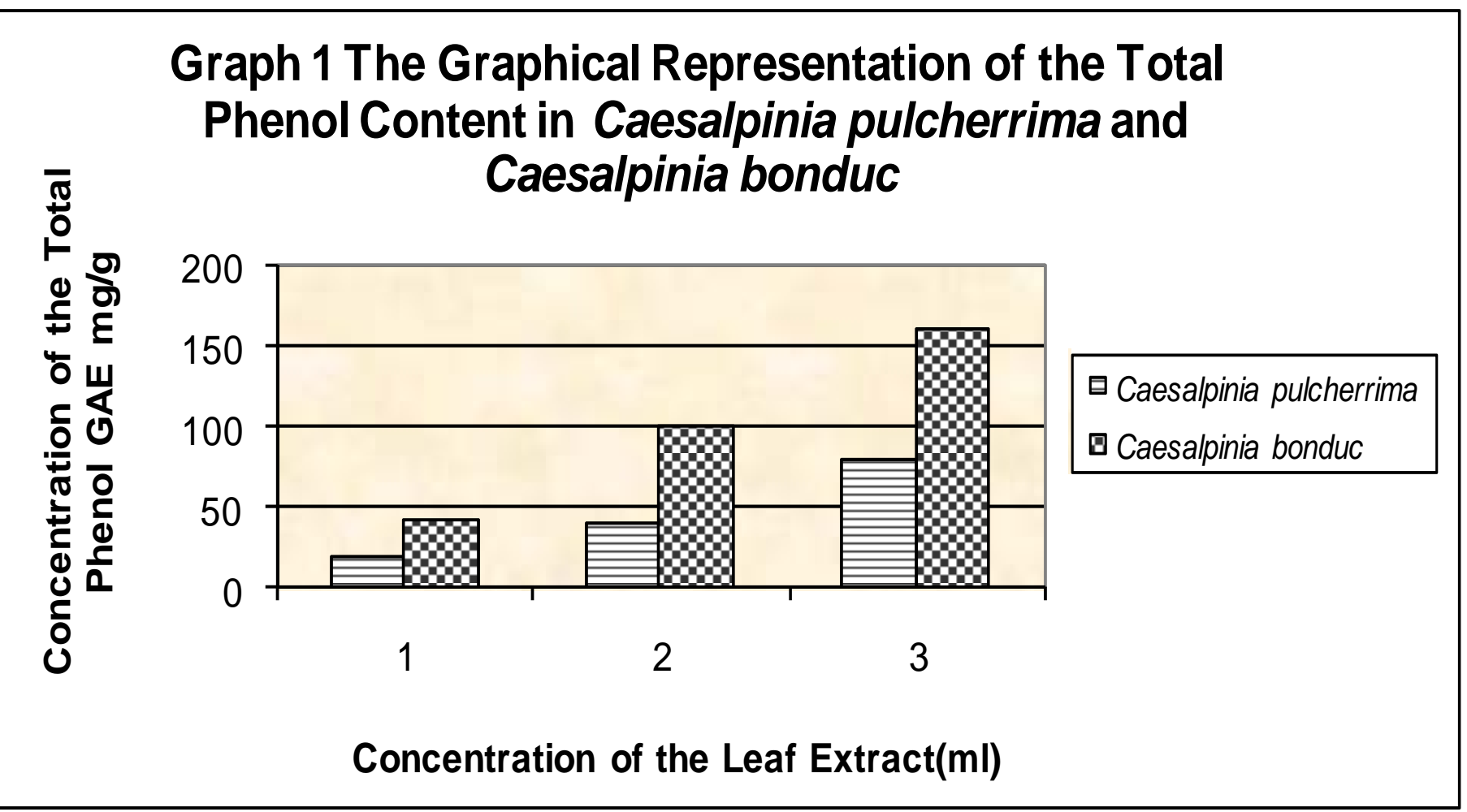


(Krishnaraju et al., 2005). Thus or in this aspect, the wild species $C$. bonduc have shown much higher values for the total phenol content estimation than the ornamental plant C. pulcherrima.

\section{Conclusion}

The experimental plants C. pulcherrima and $C$. bonduc studied here can be a potential source of useful drugs exploiting the antimicrobial, antioxidant and antitumor activities of these plants. The wild plant harbours higher values of the active ingredients than the ornamental plant which needs further research in the angle whether the domesticating factor influences the medicinal value of any plant. Further studies are being conducted on these plants in order to isolate, identify, characterize and elucidate the structure of the bioactive compounds.

\section{Acknowledgement}

The authors are thankful to the Head of the Department, Department of Botany, Pachaiyappa's college and M/S Biozone Research Technologies, Chennai for their help to carry out the experimental work.

\section{References}

1. Ali MS, Azhar I, Amtul Z, Ahmed VU and Usmanghani K (1999) Antimicrobial screening of some ceasalpiniaceaes. Fitoterapia. 70, 299-304.

2. Bailey LH (1949) Manual of cultivated plant most commonly grown in the continental United States and Canada, Macmillan company, NY. p:589.

3. Che CT, McPherson DD, Cordell GA and Fong HHS (1986) Pulcherralpin, a new diterepene ester from Caesalpinia pulcherrima. J. Nat. Proct. 49, 561-569.

4. Chiang LC, Chiang W, Liu MC and Lin CC (2003) In vitro antiviral activities of Caesalpinia pulcherrima and its related flavonoids. J. Antimicrob. Chemother. 52(2), 194-198.

5. Donglin Zhang andYasunori Hamauz (2004) Phenolics compounds and their antioxidant properties in different tissues of carrots (Daucus carota L.). Food Agri. Environ. 2(1), 95-100.

6. Evans WC (1999) Treasae \& Evan pharmacognosy. $14^{\text {th }}$ edition, Harcout Brace company, Asia Pvt Ltd, Singapore. pp: 343-346.

7. Guno SC, Rohan SB and Chaitanya RP (2009) Analgesic activity of chloroform extract of Caesalpinia pulcherrima. J. Pharm. Res. 2(7), 1199-1200.

8. Gupta M, Mazumder UK, Sambath Kumar R, Sivakumar T and Mohan Vamsi ML (2004) Antitumor activity and antioxidant status of Caesalpinia bonducella against ehrlich ascites carcinoma in swiss albino mice. J. Pharmacol. Sci. 94, 177-184.

9. Gupta M, Mazumder UK, Sambath Kumar R, Thangavel Sivakumar, Gomathi P and Rajeshwar $Y$ (2005) Antioxidant defense system induced by a
Vol. 3 No. 12 (Dec 2010)

ISSN: 0974- 6846

methanol extract of Caesalpinia bonducella in rat liver. Pharmaceutical Biol. 43, 411- 419.

10. Hill AF (1952) Economic botany. A text book of useful plants and plant products. $2^{\text {nd }}$ edn. Mcgraw-Hill book company Inc, NY.

11.Kirtikar KR and Basu BD (1935) Indian medicinal plants. Vol. 2, Periodical experts, New Delhi. pp:848.

12. Kokate CK 1999,Practoca, Pharmacognosy $4^{\text {th }}$ edition Vallaph Prakash Publication,New Delhi,India.pp:115

13. Krishnaraju AV, Rao TVN, Sundararaju D, Vanisree M, Tsay HS and Subbaraju GV (2005) Assessment of bioactivity of Indian medicinal plants using Brine shrimp (Artemia salina) lethality assay. Int. J. Appl. Sci. Eng. 2, 125-134.

14. Mace ME (1963) Histochemical localization of phenols in healthy and diseased tomato roots. Phytochem. 16, 915-925.

15.Peach K and Tracoy MV (1955) Modern methods of plant analysis. Vol.1, Springer-Verlag, Berlin. pp:523.

16. Rao YK, Fang SH and Tzeng YM (2005) Antiinflammatory activities of flavonoids isolated from Caesalpinia pulcherrima. J. Ethnopharmacol. 100(3), 249-253.

17.Srinivas KVNS, Rao YK and Mahender I (2003) Flavonoids from Caesalpinia pulcherrima. Phytochem. 63, 789-793.
"Phytochemicals in Caesalpinia spp." http://www.indjst.org
Sivasankari et al. Indian J.Sci.Technol. 